\title{
Analysis of Factors Affecting People's Satisfaction on the National Target Program for New Rural Construction in Cai Lay District Tien Giang Province (Vietnam)
}

\author{
Ngo Thanh Phong ${ }^{1}$ \\ ${ }^{1}$ Department of Economics and Law, Tien Giang University, Vietnam \\ Correspondence: Ngo Thanh Phong, Master in Economics, Department of Economics and Law, Tien Giang \\ University, Vietnam. E-mail: ngothanhphong@tgu.edu.vn
}

Received: May 17, 2021

Accepted: June 22, 2021

Online Published: July 13, 2021

doi:10.20849/abr.v6i1.911

URL: https://doi.org/10.20849/abr.v6i1.911

\begin{abstract}
The article assesses people's satisfaction about the National Target Program on New Rural Construction in Cai Lay district Tien Giang province (Vietnam). The data used in the article was collected in 2020, conducted a household survey according to a pre-designed questionnaire, with a total of 292 surveyed households. The information collected is processed using SPSS software and use the method of regression analysis to build models of the main factors affecting people's satisfaction with the results of the program. Values of variables in the model are build according to Likert scale with 5 levels (very dissatisfied $=1$; dissatisfied $=2$; neutral $=3$; satisfied $=4$; very satisfied $=5$ ). The regression results show that the main factors affecting the satisfaction of the people as the "transport system", "production reorganization", "market access", "career change" and "labor training".
\end{abstract}

Keywords: affect, satisfaction, new rural, Cai Lay

JEL codes: R11; R15; Q58

\section{Introduction}

The National Target Program on New Rural Construction is an overall program for economic, social, cultural, security and defense development in localities. New rural construction is the core of the implementation of the Central Resolution 26, dated August 5, 2008 of the 10th Central Committee on agriculture, rural areas and farmers, showing concern and care of the Party and State to develop rural areas. With the motto "The State and the people work together", building a new countryside is a revolution that promotes the synergy of the whole political system, the participation of the people, and helps people to realize responsibilities and rights in order to actively participate in and actively implement new rural construction in order to contribute to improving the material and spiritual life of rural people.

To realize the Central Resolution 26 on agriculture, rural areas and farmers, Cai Lay district Tien Giang province has implemented a pilot project to build new countryside in 7 communes in the period 2011-2020. The objective of the article is to assess people's satisfaction with the project's results after 10 years of implementation and propose some solutions to improve people's satisfaction with the project.

\section{Literature Review and Research Methods}

\subsection{Definition of Satisfaction}

According to Hoyer and MacInnis (2001), satisfaction can be associated with feelings of acceptance, happiness, help, excitement, joy.

Kotler (2000) defines satisfaction as a person's feeling of satisfaction or disappointment stemming from the comparison of actual results received after using a product (or results) in relation to their expectations.

According to Fornell (1995), satisfaction or disappointment is the consumer's response to the perceived difference between expectations before use and the actual perception of the product after consuming it.

\subsection{Introduction of the National Target Program to Build New Rural Communes}

In the spirit of Resolution 26-NQ/TW of the Central Government, new rural areas are rural areas with gradually modern socio-economic infrastructure; economic structure and forms of production organization rationally, 
linking agriculture with rapid development of industry and services; linking rural development with urban plannng according to planning; democratic, stable rural society, rich in national cultural identity; ecological environment is protected; security and order are maintained; people's material and spiritual life is increasingly improved; socialist orientation.

With that spirit, the new countryside has five basic contents. Firstly, rural areas have civilized, clean and beautiful villages with modern infrastructure. The second is sustainable, commodity-oriented production. Third, the material and spiritual life of the people is increasingly improved. Fourth, the national cultural identity is preserved and developed. Five is a well-managed and democratic rural society.

To build rural areas with the above five contents, the Prime Minister signed Decision No. 491/QD-TTg dated April 16, 2009, promulgating a set of national criteria for new rural areas reflect all aspects of economy, culture, politics, security and defense.

\section{Analytical Method}

The study surveyed 292 households using convenient sampling method. The survey subjects are farmers who benefit from the results of the national target program on building new rural areas. The data was entered into SPSS software for analysis. The survey was conducted in the fourth quarter of 2020.

\subsection{Model of Factors Affecting People's Satisfaction About the Results of the Project}

The results of the article interview identified 7 scales representing the results of the implementation of the pilot project on new rural construction and a scale for the general satisfaction of the people described in Figure 1.

\begin{tabular}{|l|l|}
\hline Transportation system (TS) \\
\hline \hline Irrigation system (IS)
\end{tabular}

Figure 1. Model of factors affecting the general satisfaction of people about the results of the project

Due to the limitation of the article, 7 representative scales are considered as standardized variables to be included in the citizen interview questionnaire with a sample size of 292 households.

From the survey results, the article will summarize the regression analysis according to the overall correlation model of the form:

$$
\mathrm{SH}=\mathrm{f}(\mathrm{TS}, \mathrm{IS}, \mathrm{C}, \mathrm{LT}, \mathrm{MA}, \mathrm{CC}, \mathrm{PR})
$$

Note: SH: is the dependent variable (Satisfaction of households);

TS, IS, C, LT, MA, CC, PR: are independent variables.

The consideration of the factors from the traffic system to the production line, which factor really affects the overall satisfaction of the people directly will be done by linear regression equation:

$$
\mathrm{SH}=\mathrm{b}_{0}+\mathrm{b}_{1} \mathrm{TS}+\mathrm{b}_{2} \mathrm{IS}+\mathrm{b}_{3} \mathrm{C}+\mathrm{b}_{4} \mathrm{LT}+\mathrm{b}_{5} \mathrm{MA}+\mathrm{b}_{6} \mathrm{CC}+\mathrm{b}_{7} \mathrm{PR}+\mathrm{e}_{1}
$$

Note: $b$ is the coefficient of regression and $e_{1}$ is the remainder.

\section{Evaluation of People's Satisfaction With the Results of the New Rural Construction Program in the Selected Communes in Cai Lay District Tien Giang Province}

After 10 years of implementing the new rural development program in 7 communes, some positive results have been achieved. Tables 1 and 2 present the model outputs of the people's satisfaction with the results of the new rural construction program in 7 communes. All are summarized as follows: 
Table 1. Regression results

\begin{tabular}{|c|c|c|c|c|c|c|c|}
\hline \multirow[t]{2}{*}{ Model } & \multicolumn{2}{|c|}{$\begin{array}{l}\text { Unstandardized } \\
\text { Coefficients }\end{array}$} & \multirow{2}{*}{$\begin{array}{l}\text { Standardized } \\
\text { Coefficients } \\
\text { Beta }\end{array}$} & \multirow[t]{2}{*}{$\mathrm{t}$} & \multirow[t]{2}{*}{ Sig } & \multicolumn{2}{|c|}{ Collinearity Statistics } \\
\hline & Beta & Std. Error & & & & Tolerance & VIF \\
\hline (Constant) & 0,120 & 0,185 & & & & & \\
\hline TS & $0,290^{(* * *)}$ & 0,042 & 0,285 & 6,831 & 0,000 & 0,524 & 1,908 \\
\hline IS & 0,011 & 0,041 & 0,010 & 0,261 & 0,794 & 0,617 & 1,620 \\
\hline $\mathrm{C}$ & 0,008 & 0,032 & 0,010 & 0,255 & 0,799 & 0,647 & 1,546 \\
\hline LT & $0,070^{(*)}$ & 0,043 & 0,065 & 1,649 & 0,091 & 0,581 & 1,720 \\
\hline MA & $0,263^{(* * *)}$ & 0,045 & 0,267 & 5,789 & 0,000 & 0,429 & 2,329 \\
\hline $\mathrm{CC}$ & $0,151^{(* * *)}$ & 0,044 & 0,145 & 3,404 & 0,001 & 0,507 & 1,971 \\
\hline PR & $0,271^{(* * *)}$ & 0,050 & 0,264 & 5,450 & 0,000 & 0,388 & 2,576 \\
\hline
\end{tabular}

$(* * *),(*)$ at the $1 \%$ and $10 \%$ significance levels, respective.

Source: Extracted from SPSS

Table 2. Factor of determination

\begin{tabular}{|c|c|c|c|c|c|c|c|c|c|}
\hline \multirow[b]{2}{*}{ Model } & \multirow[b]{2}{*}{ R Square } & \multirow{2}{*}{$\begin{array}{l}\text { Adjusted } \\
\text { R Square }\end{array}$} & \multirow{2}{*}{$\begin{array}{l}\text { Std. Error } \\
\text { of the } \\
\text { Estimate }\end{array}$} & \multicolumn{5}{|c|}{ Change Statistics } & \multirow{2}{*}{$\begin{array}{l}\text { Durbin- } \\
\text { Watson }\end{array}$} \\
\hline & & & & $\begin{array}{l}\text { R Square } \\
\text { Change }\end{array}$ & F Change & $\begin{array}{l}\mathrm{df} \\
1\end{array}$ & df 2 & $\begin{array}{l}\text { Sig. F } \\
\text { Change }\end{array}$ & \\
\hline 1 & 0,733 & 0,727 & 0,481 & 0,733 & 114,490 & 7 & 292 & 0,000 & 1,685 \\
\hline
\end{tabular}

Source: Extracted from SPSS

Table 3. Analysis of variance

\begin{tabular}{|c|c|c|c|c|c|c|}
\hline \multicolumn{2}{|l|}{ Model } & \multirow{2}{*}{$\begin{array}{l}\text { Sum } \\
\text { Squares }\end{array}$} & \multirow[t]{2}{*}{ of $\mathrm{df}$} & \multirow[t]{2}{*}{ Mean Square } & \multirow[t]{2}{*}{$\mathrm{F}$} & \multirow[t]{2}{*}{ Sig } \\
\hline & & & & & & \\
\hline \multirow[t]{3}{*}{1} & Regression & 185,727 & 7 & 26,532 & 114,490 & 0,000 \\
\hline & Residual & 67,669 & 292 & 0,232 & & \\
\hline & Total & 253,397 & 299 & & & \\
\hline
\end{tabular}

Source: Extracted from SPSS

This model has an adjusted coefficient of determination (Adjust R - Squared) of 0.727. Thus, through statistically significant independent variables, this model explained $72.7 \%$ of the variation in the general satisfaction of people about the pilot program to build new rural areas in the locality.

Table 2 shows, which independent variables have the corresponding value in the column of significance level (Sig) less than the allowable significance level of $1 \%$ and $10 \%$, then that independent variable will be statistically significant. These independent variables all have a positive effect on the change of the dependent variable because the signs of the estimators are all positive and are arranged in descending order of the beta estimators as follows: TS , PR, MA, CC and LT.

Specifically, when people evaluate the traffic system factor (TS) increased by 1 point, the people's satisfaction with the new rural construction program increased by 0.29 points (corresponding to a beta coefficient 0.290 ); when people evaluate the production reorganization factor (PR) by 1 point, their overall satisfaction with the program will increase by 0.271 points (corresponding to a beta coefficient of 0.271 ); when people evaluate the market access factor (MA) increased by 1 point, their overall satisfaction with the program will increase by 0.263 points; when people evaluate the job change factor (CC) by 1 point, their overall satisfaction with the program will increase by 0.151 points; and when people evaluate the training factor (LT) that helps people improve their professional knowledge through 
seminars, training, and vocational training increases by 1 point, their overall satisfaction with the program will increase by 0.07 points.

\section{Conclusion and Policy Implications}

\subsection{Conclusion}

The National Target Program on New Rural Construction has focused on comprehensively solving economic, cultural, social and environmental issues in Cai Lay district Tien Giang province. After 10 years of active implementation, with the high efforts of the Party Committee, administration and people of the district, the district has basically completed the set goals and tasks, obtained many encouraging results, initially created a new face in rural agriculture. The results show that there are 5 factors affecting people's satisfaction with the national target program on building new rural areas: transportation system; production reorganization; market access, career change and labor training.

\subsection{Policy Implications}

When the State's investment capital is limited, in order to further promote the effectiveness of the project, the following policies should be considered in the process of building new countryside in Cai Lay district:

Firstly, the State should focus on supporting people to reorganize their production by forming cooperative groups and economic cooperatives (cooperatives) to help farmers produce large amounts of agricultural products, high quality, low cost,... to improve the competitiveness of agricultural products in the market.

Secondly, the State needs to focus on supporting farmers in accessing the market so that people can stabilize their output for products, help them feel secure to invest, improve output and quality of agricultural products.

Third, provide vocational training for rural workers and strengthen job fair promotion after workers have been trained, helping rural workers have more opportunities to find jobs and change careers, thereby contributing to improving the material and spiritual life of people in rural areas.

Improving the lives of people in rural areas is one of the most important tasks of the authorities at all levels. Therefore, there are many programs/projects to improve the lives of people in rural areas. This article only assesses the satisfaction of the people about the National Target Program on New Rural Construction, but not with other programs/projects. The limitations of the article are also suggestive trends for further studies.

\section{References}

Cai Lay District People's Committee. (2020). Summary report of 10 years of implementation of the National Target Program on building new countryside.

Central Committee of the Communist Party of Vietnam. (2008). Resolution 26 - NQ/TW of the Xth Central Committee on agriculture, farmers and rural areas.

Fornell, C. (1995). The Quality of Economics Output: Empirical Generalizations about its Distribution and Relationship to Market Share. Marketing Science, 14(3), 203-210.

Hoyer, W. D., \& MacInnis, D. J. (2001). Consumer behaviour (2nd ed.). Boston: Houghton Mifflin Company.

Kotler, P. (2000). Marketing Management (10th ed.). New Jersey, Prentic-Hall.

People's Committee of Tien Giang Province. (2020). Report on the implementation and results of 10 years of implementing the National Target Program on building new rural areas in Tien Giang province.

Prime Minister. (2010). Decision No. 800/QD - TTg, dated June 4, 2010 Approving the National Target Program on building new rural areas for the period $2010-2020$.

Prime Minister. (2009). Decision 491/QD - TTg dated 16/4/2009 promulgating the National Set of Criteria for new rural construction.

\section{Copyrights}

Copyright for this article is retained by the author(s), with first publication rights granted to the journal.

This is an open-access article distributed under the terms and conditions of the Creative Commons Attribution license (http://creativecommons.org/licenses/by/4.0/). 